Journal homepage: www.jacsonline.org/journals/jacson

\title{
The Effects of Substitution of Corn Meal from the Concentrate of Plus-Complete Feed with Fermented Cocoa Pod on Growth of the Young Male Bali Cattle
}

\author{
Erna Hartati*, Gusti A. Y. Lestari, and A. Saleh \\ Department of Animal Science, Faculty of Animal Science, Nusa Cendana University. Jln. Adisucipto Penfui, Kupang, 85001, \\ INDONESIA
}

\begin{abstract}
Article history: Draft reached journal: 15-05-2017 Received in revised form: 06-06-2017 Accepted: 10-06- 2017
Cite this article as: Hartati E, Lestari GAY, and Saleh A. 2017. The Effects of Substitution of Corn Meal from Concentrate of Plus-Complete Feed by Fermented Cocoa Pod on Growth of the Young Male Bali Cattle. J Applied Chem. Sci. 4: 338-345, DOI: https://doi.org/10.22341/jacson.00401p338
\end{abstract}

p-ISSN: 2089-6328, e-ISSN: 2580-1953 @ 2017 JACSOnline GP. All right served

\begin{abstract}
Abstract: The study aimed to evaluate the effects of substitution of corn meal from concentrate of plus-complete feed (PCF) with fermented cocoa pod (FCP) on growth of the young male Bali Cattle. Fifteen young male Bali Cattles were randomly assigned into five groups for the substitutions of corn meal from the PCF by FCP treatments i.e 0, 25, 50, 75 and $100 \%$ which each group was replicated by three subgroups. The pods were fermented with yeast Aspergillus niger that had been activated by combinations of sugar, urea, NPK fertilizers, and various levels of $\mathrm{ZnSO}_{4}$ and $\mathrm{Zn}-\mathrm{Cu}$ isoleusinate. The best FCP, that produced $\mathrm{NH}_{3}$ and VFA in in vitro experiment, was used in the study. The results showed that substitutions of corn meal from the PCF by $100 \%$ FCP decreased signifikantly (P<0.01) Zn and $\mathrm{Cu}$ status, energy and $\mathrm{N}$ retention, and body weight gain of the young male Bali Cattles. However, the substitutions of corn meal with $0 \%$, 25\% and 50\% FCPs, those values did not decrease significant. Despite of corn meal substitutions of PCF by FCP did not decrease significantly plasma glucose and protein consumption, but substitution by FCP between of $0 \%$ and $25 \%$ did not decrease significantly protein consumption. In conclusion: the substitution of corn meal from the PCF by the FCP at the level up to 50\% can be applied without disturbance the growth of the young male Bali Cattle.
\end{abstract}

Keywords: $\mathrm{ZnSO}_{4}, \mathrm{Zn-Cu}$ isoleusinic, cocoa pod, growth, Bali Cattle

*Corresponding author: e.hartati@yahoo.com, Tel/Fax (+62)81339482960

\section{Introduction}

In previous research, we have found that technological feed formula plus complete feed (PCF) for fattening of Cattle. The PCF contained $150 \mathrm{mg} \mathrm{ZnSO} 4 \cdot \mathrm{kg}^{-1} \mathrm{DM}$ concentrate and $2 \% \mathrm{Zn}-\mathrm{Cu}$ isoleusinat. $\mathrm{kg}^{-1}$ ration $\mathrm{DM}$ diet resulted successful in increasing the weight of Bali Cattle according to their genetic potential ie $0,721 \mathrm{~kg} \cdot \mathrm{d}^{-1}$ (Hartati, dkk., 2012a). However, the amount of corn meal in the concentrate component of PCF is quite high at $46.25 \%$. Due to corn is still needed as a food source and also to use in non-ruminant and poultry feed so it is necessary to seek the alternative feed ingredients to replace a part of corn in PCF (Hartati et al., 2010).

Cocoa pod constitute the largest part of the waste cocoa, reaching 70-75.67\% (Wong et al., 1986; Darwis et al., 1988). It has been esitmated the cocoa pod dry matter production in West Nusa Tenggara and East Nusa Tenggara is around $351,713.96$ tons.year $^{-1}$. If it is assumed that the cocoa pod to replace the $50 \%$ of the forage with a ratio of forage: concentrate $60: 40$, it can accommodate as many as 120,038.80 ST (Angraeny and Umiyasih, 2008). However, cocoa pod has not been used optimally because they contain low protein $(7.17-9.36 \%)$, high crude fiber (30.16 -
$47.87 \%)$ and high lignin (27.95 - 38.78\%) (Amiroenas, 1990 and Laconi, 1998 Guntoro, et al., 2006, Anggraeny and Umiyasih, 2008), neutral detergent fiber (NDF) and acid detergent fiber (ADF) high $(66.3 \%$ and $65.1 \%)$ and the content of acid detergent lignin (ADL) $28.0 \%$ (Smith, 1974 within Sutardi, 1997). Besides, zinc (Zn) and copper $(\mathrm{Cu})$ content of ruminant dietsis low respectively $20-38 \mathrm{mg} / \mathrm{kg}$ and 8-10 ppm (Little, 1986 and Underwood, 1977), whereas the $\mathrm{Zn}$ and $\mathrm{Cu}$ very important role in the process of fermentation in the rumen and digestive enzyme activities, absorption and metabolism of nutrients. The low $\mathrm{Zn}$ content leads to decreasing of palatability and consump-tion, microbial and animal growth disturbance, decreassing the activity of the enzyme phosphatse alkaline in calf serum and carboxy peptidase A and B functioning in protein synthesis and absorption of amino acids (Miller et al., 1966; Luecke et al., 1968; Huber and Gershoff, 1973; Bettger et al., 1979 and Hartati, 2008). Trace mineral $\mathrm{Zn}, \mathrm{Cu}$, and $\mathrm{Se}$ are involved in vitamin metabolism and protein synthesis of animal (Cortinhas et al. 2010 in Cristina et al. 2012). Copper has physiological functions beside related to cellular respiration and heart function it also to bone growth (McDowell, 2003). 
Numerous authors as reported everywhere (Hartati 1998 and 2008, Hartati et al., 2009a, Larvor 1993, and Linder 1992) have suggested that enough absorption of $\mathrm{Zn}$ into metabolic system could enhance the activity of the enzyme phosphatase alkaline and carboxy peptidase possibly A and $\mathrm{B}$ respectively, which it plays an important role in energy metabolism, protein digestibility, absorption of amino acids, energy and $\mathrm{N}$ retention. Similarly, it was expected that increasing $\mathrm{Cu}$ content derived from the addition of $\mathrm{Zn}-\mathrm{Cu}$ organic could promote $\mathrm{Zn}$ absorption in the post-ruminal, thus increasing the activity of enzymes involved in the synthesis and affecting the increase of body weight gain.

Due to the hard absorption of $\mathrm{Cu}$, Hartati et al. (2012a) have conducted a research to make a high biology value of the $\mathrm{Zn}-\mathrm{Cu}$ isoleusinate organometalic compoundin a supplement form to make $\mathrm{Zn}$ appear at the post rumen. Another study reported in Hartati et al. (2012b) indicated that the quality of the CPF using Aspergillus niger activated by sugar, urea, and NPK with the addition of $\mathrm{ZnSO} 4$ and $\mathrm{Zn}$ $\mathrm{Cu}$ isoleusinate undergoing improvement. The PCF obtained from this study was CPF gives the best response to rumen fermentation and digestibility in vitro, at level of $15 \mathrm{mg}$ $\mathrm{ZnSO}_{4} . \mathrm{L}^{-1}$ aq and $200 \mathrm{mg} \mathrm{Zn}-\mathrm{Cu}$ isoleusinate. $\mathrm{L}^{-1}$ aq. However, FCP that has respond with a best results,empirically used as a substitutionof corn from the PCF which has been fed to young male Bali Cattle.

In previous research using the same experimental design (Hartati et al. 2014) studied the effects of substitution of corn meal from PCF by FCP on rumen kinetic, consumption and digestibility nutrient. Results from the research indicated that the treatment effect decreased significantly the consumption and digestibility of dry matter, organic matter, and crude protein. This results showed that treatment without substitution of the corn meal by the FCP at the level of $25 \%$ and $50 \%$ showed there has no difference in dry matter and organic matter intake. While the crude protein consumption did not decrease significantly between substitution of corn meal from PCF by 0 and $25 \%$ FCP. Furthermore, the decreased organic matter and protein digestibility between $0 \%$ to both $25 \%$ and $50 \%$ did not differ significantly, but substitution of corn meal from PCF by FCP between the level of $75 \%$ and $100 \%$ significantly decreased. Based on these results it can be showed that the substitution of corn meal from PCF by FCP at the level of $25 \%$ and $50 \%$ give consumption and digestibility values did not differ significantly; there was no difference between PCF without FCP and substituted PCF by FCP.

The objective of the present study was to evaluate the effects of substitution of corn meal from the PCF by FCP on $\mathrm{Zn}$ and $\mathrm{Cu}$ absorption, $\mathrm{Zn}$ and $\mathrm{Cu}$ plasma concentration, protein consumption, energy and $\mathrm{N}$ retention, plasma glucose, and body weight gain of the young male Bali Cattle.

\section{Materials and Methods}

\subsection{Materials}

The feed used in this study was FCP using fermented Aspergillus niger seed as a starter, urea, $\mathrm{NPK}, \mathrm{ZnSO}_{4}$ and $\mathrm{Zn}-\mathrm{Cu}$ isoleusinate that offered the best responds to the process of fermentation and digestibility in vitro. (Table 1; Hartati et al., 2012b).

\subsection{Methods}

\subsubsection{PCF concentrate preparation}

The PCF/plus complete feeds were composed of ammoniation " kume" grass and concen-trate containing 150 $\mathrm{mg} \mathrm{ZnSO}_{4} \cdot \mathrm{kg}^{-1} \mathrm{PCF} \mathrm{DM}$ and $2 \% \mathrm{Zn}-\mathrm{Cu}$ isoleusinate. $\mathrm{kg}^{-1}$ diet DM. Concentrate in PCF was composed of corn meal, coconut extract, rice bran, fish meal, coconut oil, and salt that contained $17.07 \% \mathrm{CP}$ and $78.16 \%$ TDN (Tabel 1). Concentrate in PCF supplement requires $40 \%$ of the dry matter, while the needs of dry matter is determined by $3 \%$ of body weight.

Fifteen young male Bali Cattles were used in the study and they were divided into 5 groups and replicated by 3 treatments in a group. The groups were: $\mathrm{T} 0=60 \% \mathrm{PCF}+$ $40 \%$ of ammoniation "kume": (grass and concentrates) without $\mathrm{FCP}$ ); $\mathrm{T} 1=25 \% \mathrm{PCF}$ as a substitute for corn in $\mathrm{FCP} ; \mathrm{T} 2=50 \% \mathrm{PCF}$ as a substitute for corn in FCP; $\mathrm{T} 3=$ $75 \% \mathrm{PCF}$ as a substitute for corn in $\mathrm{FCP} ; \mathrm{T} 4=100 \% \mathrm{PCF}$ without corn in FCP.

\subsubsection{Blood collection and sample analysis}

Blood sample was taken via jugularis vein and rumen fluid 3 hours after feeding to assess glucosa, $\mathrm{Zn}$ and $\mathrm{Cu}$ concentration in the blood. Variable measured were protein consumption, blood glucosa, energy and $\mathrm{N}$ retention,

Table 1. Composition of concentrate formula as a component of PCF

\begin{tabular}{|l|c|c|c|c|c|}
\hline \multicolumn{1}{|c|}{ Ingredients } & Composition & Protein $(\%)$ & TDN $(\%)$ & Protein Concentrate (\%) & TDN Concentrate (\%) \\
\hline Corn meal (\%) & 46.25 & 10.00 & 91.00 & 4.64 & 42.09 \\
\hline Rice bran (\%) & 20.50 & 10.89 & 66.00 & 2.23 & 13.53 \\
\hline Coconut cake (\%) & 23.00 & 23.10 & 74.00 & 5.31 & 17.02 \\
\hline Fish meal (\%) & 8.00 & 61.20 & 69.00 & 4.90 & 5.52 \\
\hline Lemuru oil (\%) & 1.50 & - & - & & - \\
\hline Salt (50 & 0.25 & - & - & & - \\
\hline Premix (\%) & 0.50 & - & - & & - \\
\hline ZnSO4 (mg/kg)* & 150.0 & - & - & & - \\
\hline $\begin{array}{l}\text { Zn-Cu isoleusinate } \\
(\% / \mathrm{kg}) * *\end{array}$ & 2.0 & - & - & & - \\
\hline \multicolumn{1}{|c|}{ Total } & $100 \%$ & & & 17.07 & - \\
\hline
\end{tabular}


Table 2. Composition of substances resulted from cocoa pod fermentation using Aspergillus niger and the ration at various treatments

\begin{tabular}{|l|c|c|c|c|c|c|}
\hline \multirow{2}{*}{ Compositions } & \multirow{2}{*}{ PCF } & \multicolumn{5}{c|}{ Groups of the treatments } \\
\cline { 3 - 7 } & & T0 & T1 & T2 & T3 & T4 \\
\hline Dry matter (\%) & 92.25 & 91.03 & 90.52 & 91.11 & 91.29 & 91.80 \\
\hline Organic matter (\%) & 83.13 & 91.72 & 91.74 & 91.83 & 91.22 & 91.10 \\
\hline Crude Protein (\%) & 12.18 & 12.71 & 11.79 & 11.10 & 10.75 & 10.50 \\
\hline Crude Fiber (\%) & 30.66 & 18.81 & 18.26 & 17.68 & 17.41 & 17.37 \\
\hline Fat (\%) & 2.85 & 11.01 & 10.17 & 8.83 & 8.51 & 8.27 \\
\hline CHO (\%) & 68.10 & 67.31 & 68.56 & 71.18 & 72.03 & 73,03 \\
\hline ADF (\%) & 57.18 & 53.13 & 52.87 & 52.64 & 54.27 & 55.55 \\
\hline NDF (\%) & 61.36 & 66.13 & 65.97 & 65.73 & 66.42 & 66.83 \\
\hline $\mathrm{Zn}(\mathrm{ppm})$ & 45 & 47 & 38.18 & 37.83 & 23 & 26 \\
\hline $\mathrm{Cu}(\mathrm{ppm})$ & 15.40 & 6.70 & 11.70 & 10.90 & 9.90 & 9.40 \\
\hline
\end{tabular}

Sources. Hartati et al. (2014)

Tabel 3. Average- $\mathrm{Zn}$ and $\mathrm{Cu}$ absorption, $\mathrm{Zn}$ and $\mathrm{Cu}$ concentration in serum $(\mathrm{n}=5)$

\begin{tabular}{lccccc}
\hline \multirow{2}{*}{ Zn and Cu status } & \multicolumn{5}{c}{ Groups of the treatments } \\
\cline { 2 - 6 } & $\mathrm{R} 0$ & $\mathrm{R} 1$ & $\mathrm{R} 2$ & $\mathrm{R} 3$ & $\mathrm{R} 4$ \\
\hline $\mathrm{Zn}$ absorption $(\mathrm{mg})$ & $138.19 \pm 9.15^{\mathrm{a}}$ & $149.91 \pm 14.97^{\mathrm{a}}$ & $148.57 \pm 20.78^{\mathrm{a}}$ & $104.09 \pm 10.59^{\mathrm{b}}$ & $89.76 \pm 7.83^{\mathrm{b}}$ \\
$\begin{array}{l}\text { Cu absorption (mg) } \\
\text { Zn concentration in serum } \\
\left(\mathrm{mg}^{-1} \text { ) }\right.\end{array}$ & $92.82 \pm 5.31^{\mathrm{a}}$ & $84.95 \pm 4.00^{\mathrm{a}}$ & $82.92 \pm 1.74^{\mathrm{a}}$ & $67.64 \pm 8.40^{\mathrm{c}}$ & $77.22 \pm 3.91^{\mathrm{b}}$ \\
$\begin{array}{l}\text { Cu concentration in serum } \\
\left(\mathrm{mg}^{-1} \text { ) }\right.\end{array}$ & $0.46 \pm 0.25^{\mathrm{a}}$ & $0.58 \pm 0.10^{\mathrm{a}}$ & $0.37 \pm 0.17^{\mathrm{a}}$ & $0.48 \pm 0.42^{\mathrm{a}}$ & $0.67 \pm 0.32^{\mathrm{a}}$ \\
\hline
\end{tabular}

Notes: Means of superscript different letter in the same row indicate significant differences $(P<0.05)$.

and body weight gain of the young male Bali Cattles. Crude protein consumption is the differences between feed crude protein offered and the remaining, $\mathrm{Zn}$ and $\mathrm{Cu}$ absorbed is the offerences between in the ration and faeces was determined by using AAS. $\mathrm{N}$ retention is the differences between $\mathrm{N}$ intake and $\mathrm{N}$ in faeces and urine, while energy retention is the differences between energy intake and metabolic energy in the faeces. Weighing of experimental animal was once every two week and there were 5 times of weighing during the work.

\subsection{Statistical analysis}

Data are expressed as the mean \pm SD of five independent experiments. Statistical evaluation of the data was performed by analysis of variance and the Duncan's multiple range test using SPSS package software Release 17. Statistical significant was considered at $\mathrm{P}<0.05$ or $\mathrm{P}<0.01$.

\section{Results and Discussion}

Feed used in this study consisted of ammoniation $\mathrm{Ku}$ me, standinghay grass, and concentrate consisting of corn meal, fine bran, coconut meal, fish meal, coconut oil, salt and premix. Other feed ingredients were used as substitutes cocoa pod was fermented using Aspergillus niger, which was activated by the addition of $\mathrm{ZnSO}_{4}$ and $\mathrm{Zn}-\mathrm{Cu}$ isoleusinat; the best responds to the process of fermentation and digestibility in vitro were at $15 \mathrm{mg} \mathrm{ZnSO}_{4} \cdot \mathrm{L}^{-1}$ aq and $200 \mathrm{mg} \mathrm{Zn-Cu}$ isoleusinat. $\mathrm{L}^{-1}$ aq. Composition results of cocoa pod fermentation using Aspergillus niger and the ration at various treatments and $\mathrm{Zn}$ and $\mathrm{Cu}$ status is showed in Table 2 and 3.

Supplemntation of $\mathrm{Zn}-\mathrm{Cu}$ isoleusinate on FCP, which was prepared through biofermentation prosess using Neurospora sp (yeast) by adding amino acid isoleusinate onto steamed cassava, potentially to increase rumen microorganism growth, especially cellulolitic bacteria which are important in digesting fibre (Hartati et al. 2009a). Data Table 2 showed that the decline in the content of ADF and NDF in the ration containing $25 \%$ and $50 \%$ PCF subtitution of corn, but the decrease did not show significant differences compared to the diet without PCF. While the subtitution of $75 \%$ and $100 \%$ PCF replace corn increased content of NDF and ADF. These conditions can decrease fiber digestibility levels, due to lack of available sources of carbon chain (C) and the availability of $\mathrm{N}$ and $\mathrm{Zn}$ and $\mathrm{Cu}$ were lower, then the optimal microbial protein synthesis and subsequent fermentation in the rumen disturbed.

There has been reported that an enough available content of $\mathrm{Zn}$ and $\mathrm{Cu}$ in the ration can optimize rumen microorganisms protein synthesis (Hartati et al. 2014), so that it could perform the optimal fermentation process. An increase in the content of $\mathrm{Zn}$ and $\mathrm{Cu}$ in maize substitution in FCP by $25 \%$ and $50 \%$ increase PCF even lower, but the enough fat content can increase the absorption of $\mathrm{Zn}$ (Table 3). Hartati et al. (1998; 2008 and 2009b) suggested the enough absorption of $\mathrm{Zn}$ leads to increase the activity of the enzyme phosphatase alkaline and carboxy peptidase possibly A and B respectively, which plays a role in energy metabolism, protein digestibility, and absorption of amino acids (Larvor, 1993). Cortinhas et al. (2010) reported that the $\mathrm{Zn}$ and $\mathrm{Cu}$ minerals beside involved in vitamin metabolism and the immune system of the animal, both minerals also 
involved in protein synthesis.Similarly, the increasing $\mathrm{Cu}$ content derived from the addition of $\mathrm{Zn}-\mathrm{Cu}$ isoleusinate has been reported to have much absorption in the post-ruminal, thus increasing the activity of enzymes involved in the synthesis and will affect the increase in body weight gain . Data Table 2 clearly show the content of $\mathrm{Zn}$ and $\mathrm{Cu}$ at the level of substitution of corn by $25 \%$ and $50 \%$ higher than the substitution level of corn meal by $75 \%$ and $100 \%$ PCF. Average $\mathrm{Zn}$ and $\mathrm{Cu}$ absorption and $\mathrm{Zn}$ and $\mathrm{Cu}$ concentration in plasma on various treatments are showedn in Table 3.

Based on the Table 3 data that showed higher $\mathrm{Zn}$ absorption in $60 \% \mathrm{PCF}+40 \%$ ammoniation "kume" (grass and concentrates without FCP). Then is followed by the treatments with $25 \%, 50 \%, 75 \% \mathrm{PCF}$ as a substitute for corn meal in FCP and lowers in $100 \%$ PCF without corn meal replaced by the FCP. The results indicated that treatment highly significanly $(\mathrm{P}<0.01)$ decrease $\mathrm{Zn}$ and $\mathrm{Cu}$ absorption. The decreasing of $\mathrm{Zn}$ and $\mathrm{Cu}$ absorption not significant on ration substitution of which $0, \%, 25 \%$ and 50 $\%$ corn meal of PCF by the FCP, while the difference caused by the treatment was signi-ficantly affected $(\mathrm{P}<0.05)$ to able the absorption of both $\mathrm{Zn}$ and $\mathrm{Cu}$ consumption. This condition due to the effects of the consumption decrease of the dry matter and organic matter. Rations substituted by PCF at the level of $25 \%$ and $50 \%$ showed no difference in dry matter intake (Hartati et al. 2014). Similarly, the consumption of organic matter between the ration without substituted and a substituted PCF at the level of $25 \%$ and $50 \%$ did not differ significantly. Between $50 \%$ and $75 \%$ rations were also no different, but the lowest consumption of organic matter in the ration was found at the substituted $100 \%$ by PCF. There were no differences in dry matter intake and organic matter is likely due to the flow rate of the feed ration without post-rumen and substituted at same level of $50 \%$. Beside due to the $\mathrm{Zn}$ consumption, $\mathrm{Zn}$ absorption is also because of nabati oils content in PCF as resource of the unsaturated fatty acids used as prostaglandin $\mathrm{PgE}_{2}$ syntesis precursor to increase $\mathrm{Zn}$ absorption (Hartati, 1998 and 2008a). Song and Adham (1979) stressed that $\mathrm{PgE}_{2}$ was able to increase $\mathrm{Zn}$ absorption up to $54 \%$. Hartati et al. (2012a) has also suggested that $\mathrm{Cu}$ suplementation in form of organic compound $\mathrm{Zn}-\mathrm{Cu}$ isoleusinate with hight biologis value was able to increase $\mathrm{Cu}$ absorption at post rumen and the increase up to $120 \%$ compared to basal diets without suplementation

The previous study of Hartati (1998 and 2008) and Hartati et al. (2009a; 2012a) that the supplementation 150 $\mathrm{mg} \mathrm{ZnSO}_{4} \cdot \mathrm{kg}^{-1} \mathrm{DM}$ concentrate and $2 \% \mathrm{Zn}-\mathrm{Cu}$ isoleusinate con-ducted that the increase of $\mathrm{Zn}$ absorption was able to increase enzyme alkaline phosphatase activity which functioned in energy metabolism and carboxy peptidase $\mathrm{A}$ and $\mathrm{B}$ which fuctioned in protein digestibilty and amino acids absorption, respectively. Thus, energy metabolism and amino acids absorption that leads to increase energy and $\mathrm{N}$ retention, which is in turn able to increase body weight gain of the young male Bali Cattles.

Results of the present experiment indicated that average of protein consumption, $\mathrm{N}$ and energy retention, plasma glukosa, and body weight gain of the young male Bali Cattles are reported in Table 4. The results showed that subtitution of corn meal from PCF by the FCP leaded to highly significant $(\mathrm{P}<0.01)$ decrease protein consumption, $\mathrm{N}$ and energy retention, and body weight gain, but not on plasma glucose levels. The decreasing of protein consumption was not significant on ration substitution of which $0, \%, 25 \%$ and $50 \%$ corn meal from PCF by FCP, but the difference on ration substitution for the $75 \%$ and $100 \%$ by FCP found significantly $(\mathrm{P}<0.05)$. To able effected by the consumption both of $\mathrm{Zn}$ and $\mathrm{Cu}$ on their absorption, the protein consumption as reflected by the total protein decreasing in plasma was already reported by Lestari et al. (2014) that indicated by the $\mathrm{N}$ retention decreased $(\mathrm{P}<0.01)$. However, the decreasing $\mathrm{N}$ retention in substituted corn meal at the level of $25 \%$ and $50 \%$ did not differ significantly effected (Table 4). This result is in agreement with our previous work (Hartarti, 1998 and 2008, and Hartati et al., 2012a) that amino acids absorption effected by the increase of protein consumption and $\mathrm{Zn}$ absorption.

The results indicated that subtitution of corn meal from PCF by FCP did not significant decrease the plasma glucose level. This means that FCP can be used as feeding materials to substitute corn meal of the PCF by FCP at the level of $100 \%$. This result the same as with propionic acids that might be due to the substitution of corn meal in FCP by PCF until level $100 \%$ are still capable of doing optimal propionic acids (Hartati, et al. 2014). This result also suported by Bergman et.al (1966) and Leng (1967) in Manafe (2009) that 50-54\% absorbed propionic acids might be converted to plasma glucose. Consequently, the decreasing propionic acids is due to the decreasing energy metabolism and therefore decrease the energy retention and plasma glucose levels, but in this result the decreasing plasma glucose on feed with substitution corn meal from PCF by the FCP until $75 \%$ did not significant (Table 4).

In this study, the decrease energy and $\mathrm{N}$ retention lead to decrease the body weight gain of the young male Bali Cattle. The results have indicated that substitution of corn meal from the PCF by FCP at the level $75 \%$ until $100 \%$ highly significanly $(\mathrm{P}<0.01)$ lead to decrease the body weight gain. However, substituted corn meal of the PCF by FCP at the level of $25 \%$ and $50 \%$ did not differ significantly effected. Similarly, a decrease in protein consumption, $\mathrm{N}$ and energy retention between the substitution of $25 \%$ to $50 \%$ which was found that there is no significant diffe- rence. Based on these results, the substitution of corn meal from the PCF by FCP at the level of $25 \%$ and $50 \%$ give protein consumption, $\mathrm{N}$ and energy retention, and plasma glucose levels did not differ significantly. 
Table 4. Average protein consumption, $\mathrm{N}$ and energy retention, plasma glucose and body weight gain of young male Bali Cattles

\begin{tabular}{|c|c|c|c|c|c|}
\hline \multirow{2}{*}{ Item } & \multicolumn{5}{|c|}{ Groups of the treatments } \\
\hline & R0 & R1 & $\mathrm{R} 2$ & R3 & $\mathrm{R} 4$ \\
\hline $\begin{array}{l}\text { Protein consump-tion } \\
\left(\mathrm{g} \cdot \mathrm{d}^{-1}\right)\end{array}$ & $386.2 \pm 11.7^{\mathrm{a}}$ & $380.3 \pm 9.0^{\mathrm{a}}$ & $368.2 \pm 11.7^{\mathrm{b}}$ & $360.1 \pm 15.7^{\mathrm{b}}$ & $339.5 \pm 12.7^{\mathrm{c}}$ \\
\hline $\mathrm{N}$ retention $\left(\mathrm{g} \cdot \mathrm{d}^{-1}\right)$ & $40.4 \pm 1.1^{\mathrm{a}}$ & $37.1 \pm 3.2^{\mathrm{a}}$ & $32.3 \pm 5.5^{c}$ & $29.3 \pm 2.6^{\mathrm{b}}$ & $25.1 \pm 1.2^{\mathrm{d}}$ \\
\hline $\begin{array}{l}\text { Energy retention } \\
\left(\text { Kcal. }^{-1}\right)\end{array}$ & $10423.5 \pm 786.3^{\mathrm{a}}$ & $10480.4 \pm 783.0^{\mathrm{a}}$ & $10357.4 \pm 853.3^{\mathrm{a}}$ & $10227.9 \pm 580.3^{\mathrm{a}}$ & $9083.1 \pm 492.8^{\mathrm{b}}$ \\
\hline Plasma glucose & & & & & \\
\hline$\left(\mathrm{mg} \cdot \mathrm{dL}^{-1}\right)$ & $84.36 \pm 4.36^{\mathrm{a}}$ & $83.98 \pm 3.32^{\mathrm{a}}$ & $83.77 \pm 1.44^{\mathrm{a}}$ & $82.50 \pm 9.66^{\mathrm{a}}$ & $81.91 \pm 8.87^{\mathrm{a}}$ \\
\hline $\begin{array}{l}\text { Body weight gain } \\
\left(\text { g.d } \mathrm{d}^{-1}\right)\end{array}$ & $269.2 \pm 71.4^{\mathrm{a}}$ & $265.0 \pm 14.8^{\mathrm{a}}$ & $235.0 \pm 72.9^{\mathrm{a}}$ & $192.3 \pm 12.3^{b}$ & $76.9 \pm 25.6^{\mathrm{c}}$ \\
\hline
\end{tabular}

Notes: Means of superscript different letter in the same row indicate significant differences $(P<0.05)$.

\section{Conclusion}

Based on these results, it can be concluded that the substitution of corn meal of PCF by FCP at the level of $25 \%$ and $50 \%$ give plasma glucose, $\mathrm{N}$ and energy retention, and daily body weight gain of the young male Bali Cattles did not differ significantly difference compared with ration intakes between the PCF and the corn meal substitution from the PCF by the CFP. This means that FCP can be used as feeding material to substitute corn meal of the PCF at the content up to $50 \%$ level.

\section{Acknowledgement}

Great thanks to the Directorate General of Higher Education who had provided the fund for this research and it is a part of the result of Hibah Bersaing executed at 2012 and HKSN 2013-2014 under the coordination of the research institute of Nusa Cendana University Kupang.

\section{References}

Amiroenas DE. 1990. Mutu Ransum Berbentuk Pelet dengan Bahan Serat Biomasa Pod Coklat (Theomoma cocoa L) untuk Pertumbuhan Sapi Perah. Tesis. Program Pasca Sarjana, IPB, Bogor.

Andrea F, Fustin M, Arshetti L, Emanuele S, Sniffen C, and Biagi G. 2011. Effects of an Organic Source of Copper, Manganese and Zinc on Dairy Cattle Productive Performance Health Status and Fertility. Abstract. Animal Feed Sience and Teknology.

Anggraeny YN, dan Umiyasih U. 2008. Evaluasi Potensi Pakan Asal Limbah Tanaman Pangan dan Perkebunan di Daerah Proritas Kawin Alam Mendukung Program P2SDS. Pros. Seminar Nasional Teknologi Peternakan dan Veteriner.Bogor. 11-12 Nov. 2008. Puslitbang Peternakan, Bogor. Hal. 304-311

Bettger WJ, Reeves PG, Moscatelli EA, Reynolds G, and O’Dell BL. 1979. Interaction of Zinc and Essential Fatty Acids in Rat. J. Nutr.109: 480-488.

Cortinhas CS, Botaro BG, Sucupira MCA. 2010. Antioxidant enzyme s and Somatic Cell Count in Dairy Cows fed with organic source of Zinc, Copper and Selenium. Livestock Sience. V 127, n 1, p84-87. DOI: https://doi.org/10.1016/j.livsci.2009.09.001

Cortinhas CS, de Freitas Junior JE, de Rzende Neres J, de Felicio Porcianot MA. 2012. Organic and in organic Sources of Zinc, Copper and Selenium in Diet for Dairy Cows intake, Blood Metabolic Profile, milk Yield and Composition. Abstract. Zootec. Vol 41, no. 6
Darwis AA, Sukara E, Tun Tedja dan Purnamawaty R. 1988. Bioconversi Limbah Ligno Selulosa oleh Trichoderma viridae dan aspergillus niger. PAU Bioteknologi, IPB, Bogor.

Guntoro S, Sryanto SN, dan Yasa MR. 2006. Pengaruh Pemberian Limbah KakaoOlahan terhadap Pertumbuhan Sapi Bali. Prosiding Seminar Nasional Teknologi Peternakan dan Veteriner. Puslitbang, Badan.LITBANG .Pertanian Bogor.

Hartati E. 1998. Suplementasi Minyak Lemuru dan Seng ke dalam Ransum yang mengandung Silase Pod kakao dan Urea untuk Memacu Pertumbuhan Sapi Holstein Jantan. Disertasi. Program Pasca Sarjana, IPB. Bogor.

Hartati E. 2008. Efek Suplementasi Minyak Lemuru dan ZnSO4 pada Ransum yang Mengandung Silase Pod Kakao dan Urea terhadap Absorpsi Zn dan Pertumbuhan Sapi Jantan. Jurnal Produksi ternak.10: 50-54.

Hartati E, Katipana NGF, and Saleh A. 2009a. Penambahan Seng pada Pakan Padat Gizi Mengandung Minyak Lemuru untuk Meningkatkan Pertumbuhan dan Berat Lahir Sapi Bali. Journal Animal Production. 11 (1): 59-65.

Hartati E, Saleh A, and Sulistijo ED. 2009b. Optimalisasi Proses Fermentasi Rumen dan Pertumbuhan Sapi Bali Melalui suplementasi Zn$\mathrm{Cu}$ isoleusinat dan $\mathrm{ZnSO} 4$ pada Ransum Basbasis Standinghay Rumput Kume (Andropogon timorensis) Amoniasi. Fapet Undana. Kupang

Hartati E, Saleh A, dan Sulistidjo ED. 2010. Suplementasi Zn-Sulfat Dan $\mathrm{Zn}-\mathrm{Cu}$ Isoleusinat Dalam Ransum Berbasis Pakan Lokal Untuk Pening- katan Produktivitas Dan Kekebalan Tubuh Sapi Bali.Fakultas Peternakan, Undana, Kupang

Hartati E, Saleh A, Sulistijo ED, and Ratuwaloe JJA. 2012a. Supplementation of $\mathrm{ZnSO} 4$ and $\mathrm{Zn}-\mathrm{Cu}$ Isoleusinate in Ration to Improve Growth and Body Immunity of Young Male Bali Cattle. J. Animal Production. UNSOED 14 (3):180186.

Hartati E, Lestari GAY, and Saleh A. 2012. Substitusi Jagung pada Pakan Komplit Plus oleh Pod Kakao Hasil Fermentasi Menggunakan Zn-Cu isoleusinat untuk Mengoptimalkan Fermentasi Rumen dan Pertumbuhan Sapi Bali. Fakultas Peternakan, Undana Kupang.

Hartati E, Lestari GAY, and Saleh A. 2014. Substitution Effect of Corn in Plus Complete Feed by Pod Cocoa Result of Fermentation using Aspergillus niger to Rumen Kinetic and Digestibility of Young Male Bali Cattle. Proceding of the AAAP Animal Sience Congress, UGM, Yogyakarta, Indonesia.

Huber AM and Gershoff SN. 1973. Effect of dietary zinc. Zinc of zinc enzymes in the rat. J. Nutr. 103: 1175-1181.

Laconi EB. 1998. Peningkatan Mutu Pod Kakao Melali Amoniasi dengan Urea dan Biofermentasi dengan Phanerochaete chrysossporium serta Penjabarannya ke dalam Formula Ransum Ruminansia. Disertasi. Program Pascasarjana, IPB. Bogor 
Larvor P. 1993. The Pool of Celluler Nutrients Mineral. In Dynamic Biochemistry of Animal Production. P.M. Riis. Ed, Elsever, Amsterdam.

Lestari GAY, Hartati E and Kodi FKH. 2014. Total Protein Plasma dan Kadar Haemoglobulin Darah Sapi Bali yang Mendapat Pakan Komplit Plus dengan Pod Kakao Hasil Fermentasi Menggunakan Aspergillus nigger sebagai Pangganti Jagung. Prosiding. Seminar Nasional Peternakan Berkelanjutan 6. Fakultas Peternakan Universitas Padjadjaran. ISBN: 978-602-14788-8-2. Hal.261-269

Linder MC. 1992. Biokimia Nutrisi dan Metabolisme. Universitas Indonesia Press. Jakarta

Little DA. 1986. The Mineral Content of Ruminant Feed and the Potensial for Mineral Supplementation in South-East Asia with Particular Reference to Indonesi. In R. M. Dixon Ed. Ruminant Feeding Systems utilizing Fibrous Agricultural Resideus, Canberra.

Luecke RW, Olman ME and Baltzer BV. 1968. Zinc Defiency in the Rat: Effect on

Anonymous, Serum and Intestinal Alkaline Phosphatase activities. J. Nutr, 99: 344-351.

Manafe J, Katipana NGF and Hartati E.2009. Kinetikan Perombakan Protein Limbah Organik di dalam Rumen Berdasarkan Persamaan Michaelis minten dan Manfaatnya bagi Ternak. Fakultas Peternakan, Undana, Kupang
McDowell LR. 2003. Miniral and Animal and Human Nutrition. 2ed. Netherlands.Elsevier Science. $644 \mathrm{p}$

Miller WJ, Wood AS and Yao YT. 1966. Influence of Zinc deficiency on dry matter digestibility in ruminants. J. Dairy Sci. 49:10121013. DOI: $\quad$ https://doi.org/10.3168/jds.S00220302(66)88108-0

Song MK.and Adham NF.1979. Evidence for an Important Role of Prostaglandins E1 and E2 in the Regulation of Zinc Transport in the Rat. J. Nutr. 109: 2152-2159.

Spears JW, Weiss WP. 2008. Role of antioxidants and Trace Mineral Elements in Health and Immunity of Transition Dairy Cows. The Veterinary Journal. V 176, n 1, p 70-76. DOI: https://doi.org/10.1016/j.tvj1.2007.12.015

Sutardi T. 1997. Ikhtisar Ruminologi. Bahan Penataran Kursus Peternakan Sapi Perah di Kayu ambon, Lembang, Bogor. DepartemenIlmu Makanan Makanan Ternak, Fakultas Peternakan, IPB, Bogor

Underwood EJ. 1977. Trace Mineral in Human and Animal Nutrition. 4 th. Ed.. Academic Press, New York.

Wong HK., Osman AH, and Idris MSM. 1986 Utilization of Cocoa by Product as Ruminant Feed. In. R.M. Dixon (Edit) Ruminant Feeding Systems Utilizing Fibrous Agricultural Residues.

All authors have no conflict of interest relating financial support and/or preparation of the manuscript 